\title{
ESTUDIOS
}

\section{Tupamaro de Caxamarca: tonadas sobre la muerte del Inca Atahualpa contenidas en el códice Martínez Compañón (1782-85)}

\author{
Tupamaro de Caxamarca: Tunes about the \\ Death of the Inca Atahualpa contained in the \\ Codex Martinez Compañón (1782-85)
}

\author{
por \\ Tiziana Palmiero \\ Investigadora asociada Proyecto FONDECYT No 1090110 \\ Directora Conjunto Capilla de Indias. \\ tizianapal@hotmail.com
}

\begin{abstract}
A lo largo de la Colonia se va construyendo una memoria de la historia de los pueblos andinos que considera al Imperio incaico como su principal referente y a la figura del Inca ${ }^{1}$ como su símbolo natural. La narración de los hechos de la historia incaica, en especial aquellos relativos a la conquista española, generaron el mito de la muerte del Inca ${ }^{2}$, a la cual habrán contribuido colonizados y colonizadores. Durante el siglo XVIII serán numerosas las representaciones teatral-musicales de estos hechos.

El códice Martínez Compañón (1782-85) consta de nueve tomos con alrededor de 1.500 láminas en colores que ilustran los diferentes aspectos de la vida social y natural de la zona de Trujillo, Perú. Treinta y ocho láminas, incluidas en el tomo II, se refieren directa o indirectamente a la música de tradición oral de la época, las láminas numeradas -foliación original, E. está por "Estampa"-desde la E.176 hasta la E.193 contienen un total de veinte partituras. A primera vista el título de las dos tonadas: "E.188: Allegro tonada El tupamaro, Caxamarca" y "E.191 (b): Adagio tonada el Tuppamaro de caxamarca" sugiere que el contenido de las mismas podría tener relación con los sucesos de Cajamarca, es decir, con la captura y muerte del Inca Atahualpa ${ }^{3}$. En el mismo tomo II se encuentran además dos láminas que representan la decapitación del Inca: “Danza de la degollación del Ynga E.172; E.173.”. De
\end{abstract}

${ }^{1}$ Una larga tradición oral activa en los Andes y alimentada por las crónicas, dibujos, poesías y representaciones teatrales, anuncia el retorno del Inca y la restauración del Imperio. Este fenómeno ha sido estudiado por varios autores, entre los cuales destacan Alberto Flores Galindo, Manuel Burgas, Mercedes López Baralt.

${ }^{2} \mathrm{E}$ Inca Atahualpa fue ejecutado en el garrote en 1533, pero rápidamente se divulgó la creencia de su decapitación. El documento más importante sobre el cual reposa este mito es seguramente Nueva corónica y buen gobierno que escribió Felipe Guamán Poma de Ayala en 1615.

${ }^{3}$ El 15 de noviembre de 1532 Francisco Pizarro llega a la ciudad de Cajamarca pidiendo una audiencia con el Inca Atahualpa que se encontraba en los Baños de Cajamarca. El encuentro se lleva a cabo en la plaza de Cajamarca donde los españoles capturan al Inca. Durante los meses de cárcel Atahualpa reúne muchas riquezas para pagar su rescate, pero esto no será suficiente para salvarle la vida. 
ser así las dos tonadas podrían ser dos fragmentos musicales únicos de las representaciones teatrales antes mencionadas ${ }^{4}$.

Durante el análisis de las dos partituras encontramos que éstas tendrían relación con otras partituras del mismo códice: "E. 191, Magestuoso Cachua la Despedida de Guamachuco"; "E. 190 Allegro tonada la brugita para cantar de Guamachuco" y "E.187, Andantino Tonada El Diamante, para baylar de Chachapoyas". Se trató de analogías musicales o textuales que permitieron crear un hilo conductor con los trágicos hechos de Cajamarca. Pero más allá de determinar si algunas de las tonadas del Códice pudieran ser parte de una representación de la captura y muerte de Atahualpa de finales de la colonia, nos interesó interpretar estos cantos como signos portadores de un discurso colonial propio en dos sentidos: la relectura de hechos históricos cuales la captura y la muerte de Atahualpa; la persistencia de códigos andinos en la rememoración de ciertos rituales como el "llanto ceremonial". En este sentido se consideró, para el análisis musical, la existencia de un tono -visto en un primer momento como elemento perteneciente a un sistema de tonos incaicos cercano al sistema de modos eclesiásticos-, que llamaremos "llanto del Inca", su relación con el llanto ceremonial incaico y su rol en la transmisión de significados ligados a la ritualidad andina colonial.

Palabras clave: música colonial, tono, Inca Atahualpa, códice Martínez Compañón, historia andina, muerte del Inca, historia colonial.

Throughout the colonial period a memory of the history of the Andean tribes was created. This memory considered the Inca empire as its main reference and the Inca as its natural symbol. From the narration of the facts of the Inca history, particularly those referring to the Spanish conquest, sprang up the myth of the Inca death to which contributed both conquerors and those who were conquered. During the eighthteenth century the death of the Inca was presented in numerous theatrical performances accompanied with music.

The codex Martinez Compañon (1782-85) consists of nine volumes with about 1500 color plates depicting different aspects of both the social life and the natural phenomena of the Trujillo zone in Peru. Thirty eight plates, included in volume II, are related directly or indirectly with music of oral tradition of the period. The original folio numbers of these plates are all preceded by the letter E, standing for "estampa" (plate). A total of twenty scores appear between E. 176 though E. 193. Judging from the title the text of the following two tunes - E 188: Allegro tonada El tupamaro, Caxamarca" and "E. 191 (b): Adagio tonada el Tuppamaro de caxamarca"-could be related to the events of Cajamarca leading to the capture and death of Inca Atahualpa. The same volume II contains two other plates depicting the beheading of the Inca: "Danza de la degollación del Inga E 172; E 173 ". If this were the case these two tunes could be the only remaining musical fragments of the theatrical performances mentioned above.

As a result of the analysis of these two scores we discovered that they could bear a relationship with other scores of the same codex on the basis of musical or text analogies which could be traced back to the tragic events of Cajamarca. These scores are the following: "E. 191, Magestuoso Cachua la Despedida de Guamachuco"; "E. 190 Allegro tonada la brugita para cantar de Guamachuco" and "E. 187. Andantino Tonada El Diamante, para baylar de Chachapoyas". However our main interest was not to ascertain whether some "tonadas" of the codex could have been part of a theatrical performance of the capture and death of Atahualpa at the end of the colonial period. Indeed we are interested in interpreting these chants as bearing signs of a colonial discourse in two different aspects. On the one hand, the reinterpretation of such historical facts as the capture and death of Atahualpa, and on the other the lingering on of Andean codes in the remembrance of certain rituals such as the "ceremonial grieving". For the sake of musical analysis it was established the existence of a mode conceived initially as part of a system of modes of the Inca era related to the system of European church modes. We have named this mode as "Inca grieving" and we will consider its relationships with the ceremonial grieving of the times of the incas as well as its role in the transmission of meanings related to the colonial Andean rituals.

Key words: colonial music, mode, Inca Atahualpa, codex Martínez Compañon, Andean history, death of the Inca, colonial history.

${ }^{4}$ Es necesario mencionar que otros autores, como los musicólogos Samuel Claro Valdés y Carlos Vega, se refieren a las mismas láminas musicales y dibujos como una "referencia al descuartizamiento de Túpac Amaru y algunos de sus familiares" (Claro 1980:21) como consecuencia de las revueltas indígenas acaecidas entre 1780 y 1783. 
El sistema de $\operatorname{modos}^{5}$ eclesiásticos usados por los evangelizadores buscaba una relación entre una escala y estructura melódica, y la naturaleza humana. Este sistema musical derivó en la época barroca en la teoría de los afectos. En este sentido un modo específico podía mover el alma humana a ciertas emociones o estados del espíritu. Estos modos se fueron definiendo a lo largo de la historia, desde las teorías pitagóricas, pasando por Boecio, hasta los escritos de Atanasius Kircher, ${ }^{6}$ siglo XVII y el tratado de Pablo Nassarre, siglo XVIII, en un conjunto de características que ponían en relación la música con el cuerpo humano, los sentimientos y los cuerpos celestes. En el fondo un determinado modo musical provocaría una cierta reacción por tener analogías con algunas características del ser humano.

En las crónicas coloniales, el término tono o tonada referido a la cultura incaica, indica la presencia de una relación precisa entre las características de la música ejecutada y el contexto de su ejecución.

\section{El Inca Garcilaso de la Vega así lo explica:}

"Cada canción tenía su tonada conocida por sí, y no podían decir dos canciones diferentes por una tonada [...] Y esto era porque el galán enamorado dando música de noche con su flauta, por la tonada que tenía dezía a la dama y a todo el mundo el contento y descontento de su ánimo, conforme al favor o disfavor que se le hazía. Y si se dixieran dos cantares diferentes por una tonada, no se supiera cual de ellos era el que quería decir el galán. De manera que se puede decir que hablava por la flauta”. (2005:129).

El texto parece indicar que un tipo de melodía interpretada por un instrumento tendría, dependiendo de su estructura compositiva, un significado extramusical determinado. Al decir un tipo de melodía se entiende un conjunto de características como ritmo; escala; tiempo; inflexión melódica. Estas melodías, cuando eran cantadas, podían tener un texto acorde al significado del "tono". En este sentido era oportuno crear textos breves para poder ser aprehendido fácilmente por el instrumento.

La cercanía que pudieron vislumbrar los misioneros españoles entre el sistema musical de tonos o tonadas incaicos, que corresponde probablemente a una escala musical, una forma musical y un contenido y el sistema de los modos musicales eclesiásticos, con características parecidas, pudieron facilitar el mestizaje entre las dos "teorías" musicales. Algunas de las melodías de las tonadas objeto de estudio, parecen inspirarse en un único modelo "compositivo". Esto refuerza la idea de pertenecer a una única unidad significante, que podría aquí denominarse el tono de la "muerte del Inca".

\footnotetext{
${ }^{5}$ Se trata de la diferente posición de una escala al interior de un sistema perfecto e inmutable. Esto genera un sistema de ocho escalas que se diferencian por la posición de los intervalos de tonos y semitonos. Cada "modo" corresponde a una de las ochos escalas litúrgicas, caracterizadas por un sonido fundamental y la diferente posición de tonos y semitonos.

6“Atanasius Kircher, en el capítulo VI del libro VII [define que] ocho son los efectos que se pueden expresar musicalmente: amor, dolor/llanto, leticia/exultación, furor/indignación, compasión/lágrimas, temor/aflicción, presunción/audacia, admiración/estupor” (Bianconi 1982:56).
} 
La musicóloga Anna Gruszczynska, en su libro El poder del sonido (1995), dedica un amplio espacio a la descripción de lo que podrían ser los Tonos Incaicos -así como se desprende de las crónicas coloniales. Los define como un conjunto de características rítmico-melódicas que tendrían relación con un determinado contexto situacional. Para nosotros, siguiendo esta misma línea, la reproducción de un tono no provocaría simplemente un estado del alma, como sería el caso de los modos occidentales, sino que evocaría una precisa situación ceremonial, convirtiéndose en un importante vehículo de identidad colectiva.

En este sentido, la posible existencia de un tono denominado "llanto del Inca" en una representación teatral de finales de la colonia vendría a significar, para un oyente o participante andino, no solamente un momento de catarsis colectiva, sino que la posibilidad de sentir y de vivir ceremonialmente y en comunidad la muerte del Inca y su posible retorno, y por lo tanto de percibir y reafirmar su existencia como comunidad andina.

Desde el punto de vista metodológico, el análisis de los diferentes mensajes transmitidos por las láminas musicales del códice Martínez Compañón precisa del estudio de tres soportes o códigos: las partituras, los dibujos y los textos. Estos signos no tienen relación directa entre sí, o sea, no son uno la traducción del otro. Son de alguna manera signos complementarios, capaces de significar por sí solos que pueden iluminar de un nuevo sentido los signos vecinos. Podrían ser considerados uno como el interpretante del otro, o también como signos referidos a las mismas unidades culturales operantes en un mismo universo semántico de referencia.

Por el contrario, el conjunto de los signos del códice puede ser considerado como la traducción de una función sígnica operante externamente al códice mismo, en este caso una representación de la muerte de Atahualpa acaecida en Trujillo, entre 1782 y 1785.

En el momento de analizar las diferentes tonadas, nos dimos cuenta de algunas diferencias entre la relación de los soportes entre sí y con el objeto representado. Aparentemente la relación texto-música crea una unidad significativa a parte de las láminas figurativas. Si bien los dibujos y las tonadas podrían compartir el contexto de significación -la representación de la muerte de Atahualpa- no comparten necesariamente el mismo objeto denotado. En las tonadas, texto y música se refieren al mismo momento significativo, es decir, comparten una dimensión temporal sobre la cual se construyen ambos soportes. Si bien una transcripción y un texto escrito son en estricto rigor imágenes, en el momento de decodificar estos signos estamos obligados a hacer intervenir el tiempo como un elemento de articulación del mensaje para que este último sea significativo.

En el caso de las acuarelas, la relación con la unidad texto-música vendría a ser de tipo contextual, ya que sirve para reforzar y posicionar los mensajes-tonadas en un evento macro que los contiene. Es decir, las acuarelas "Danza de la degollación del Inca" sitúan inmediatamente a las dos tonadas "El Tupamaro de Caxamarca" en el marco de una representación teatral-coreográfica de los hechos de Caxamarca. Además, la elección del argumento representado: el sueño de Atahualpa y la degollación de Atahualpa nos entrega la dimensión de la importancia de estos, por lo menos para el transcriptor-dibujante, al interior del drama. Las imágenes 
se presentan entonces como una clave de lectura de las tonadas, que ayuda a encontrar el foco de análisis de las mismas.

Con respecto a la relación entre música y texto, podemos decir lo siguiente. Si la música de las tonadas se construye en base a un tono, este se encargaría de ubicar al posible oyente, un oyente culturalmente experto, por ejemplo, un andino, en un ambiente emocional y situacional determinado. De hecho, en este trabajo se afirma que los tonos no transmiten emociones solamente, sino que pueden entregar connotaciones referidas a una situación en especial; un determinado comportamiento; un sentido de identidad. La reproducción de un tono, provocaría una respuesta precisa del productor-oyente; una respuesta en término de comportamiento social; de expresión emocional no subjetiva; de sentido de identidad colectiva.

En este sentido, el rol del texto se define en la declaración de un preciso aspecto a observar. En el caso del tono "llanto del Inca”, la música describe el llanto ceremonial para la muerte del Inca, con todas sus connotaciones -pensando en una performance a finales de la colonia, en época post-revolución, Tupac Amaru II ${ }^{7}$ - esto es, la evocación de un pasado feliz; la esperanza del retorno del Inca; la tragedia de la conquista. Por otro lado los textos de las tonadas subrayan algunos aspectos específicos de este gran relato: un hecho histórico; una emoción; un detalle significativo.

Los modos europeos -sobre cuya filosofía se basa buena parte de nuestra concepción de la música- son significativos en cuanto apelan a la naturaleza humana. Los tonos en cambio interpelan al ser humano ubicándolo en un momento preciso y significativo de su cultura.

\section{LAS LÁGRIMAS DEL INCA Y EL DIAMANTE}

En las dos partituras “Tupamaro de Caxamarca, E. 188 y E. 191” (Ver ejemplos Nos 1 y 2), las indicaciones musicales en el título dicen: Allegro Tonada; Adagio Tonada. La primera es una medición temporal, la segunda indicación corresponde a un género musical, la tonada. Hoy en día se entiende por tonada una composición poética para ser cantada; este género se encuentra arraigado en toda Hispanoamérica.

En el caso de la tonada 188, el tempo Allegro se refiere solamente a la introducción instrumental, que servía probablemente también de coda o de interludio en el caso posible de varias estrofas. La parte del canto es un Grave, lo que correspondería a un pulso bastante más lento. El tempo es 2/4, con uso de tresillos en el Grave.

La pieza tiene un sostenido (\#) en armadura y está escrita en una aparente tonalidad de Mi menor con oscilaciones constantes al tercer grado de la escala, Sol mayor. La extensión del canto es de una quinta Re-La, con una excursión al

7Tupac Amaru II es José Gabriel Condorcanqui, caudillo que capitaneó la mayor rebelión anticolonial. La insurrección empezó en 1780 y terminó el 18 de mayo de 1781 con la ejecución de Gabriel y de toda su familia en la Plaza del Cuzco. 

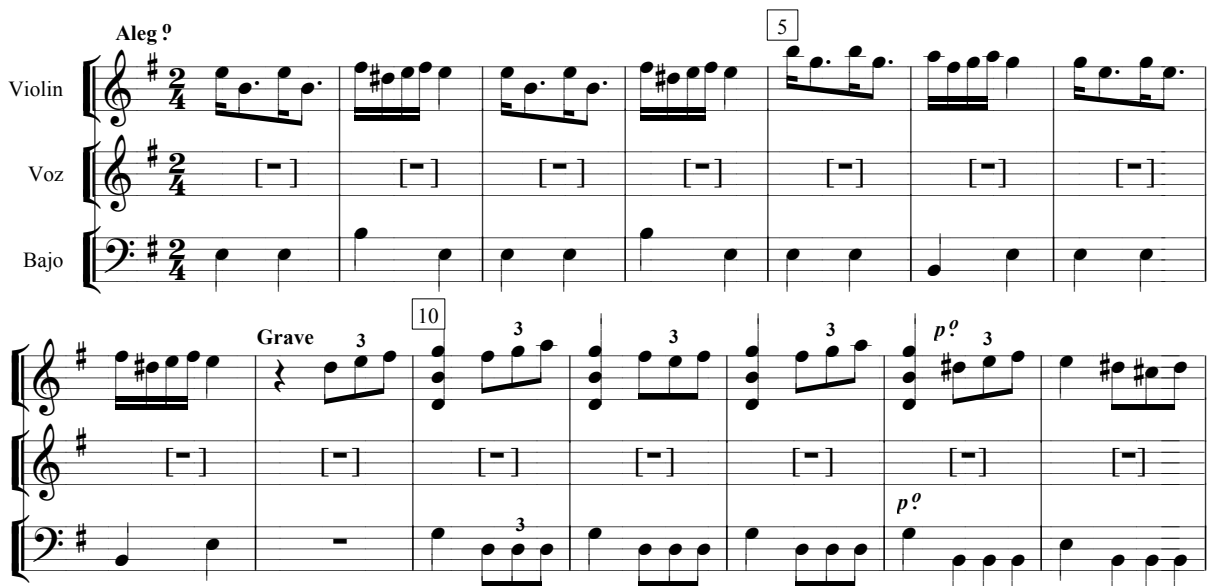

15
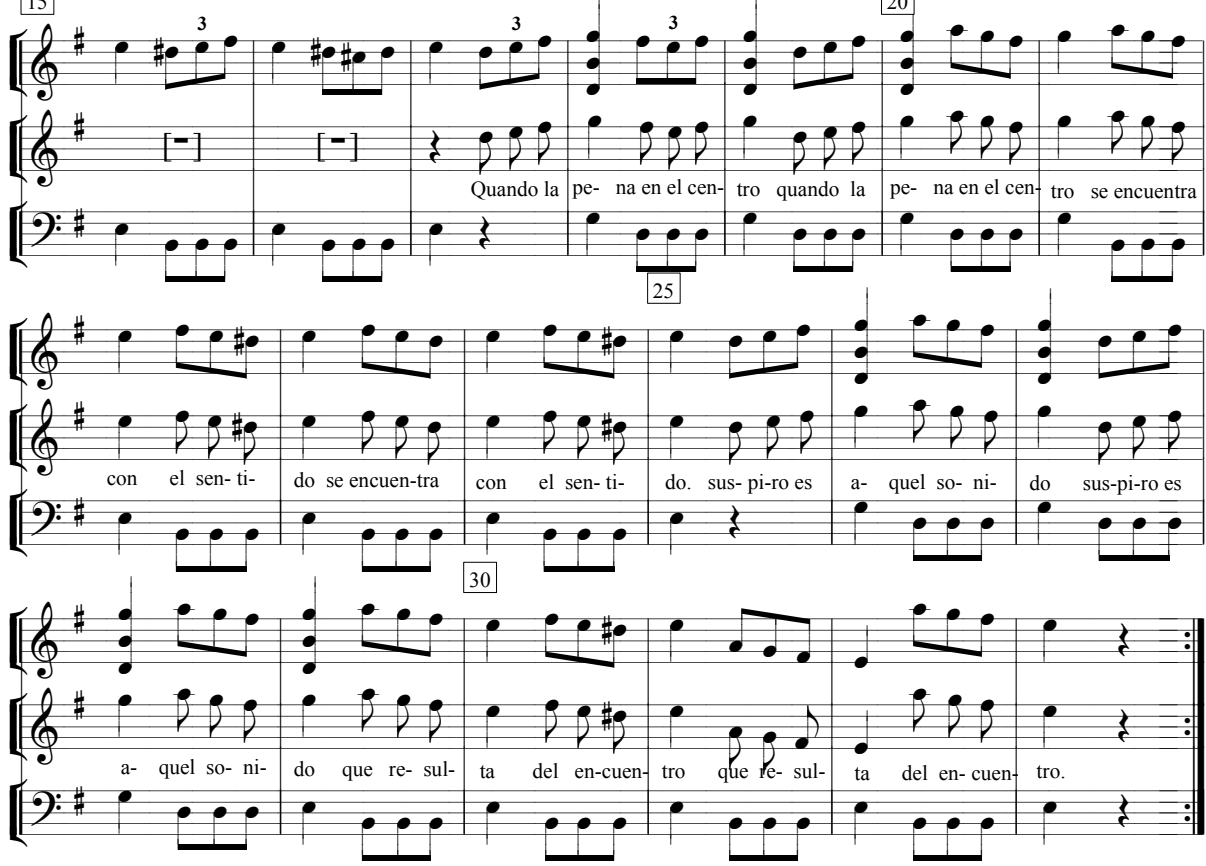

Ej. Nº 1. Tonada el Tupamaro. Martínez Compañón, II, fol. E. 188.

Re\# cuando la armonía acentúa el Mi menor. La melodía instrumental tiene una extensión de una octava sin pasar por el sexto grado, es decir, de $\mathrm{Si}$ a $\mathrm{Si}$ sin pasar por el Do. El Do tampoco aparece en el acompañamiento, ya que los acordes derivados por el bajo y la melodía son: Sol, Mi menor, Re, Si. Se trataría por lo tanto de una escala pentatónica con un pasaje al segundo grado del Mi menor, el Fa\#, que cumple función de sensible de Sol. La melodía de esta tonada está 
construida en una típica escala pentatónica andina, cuyas notas gravitacionales son la fundamental y la tercera (Mi y Sol):

$$
\text { Mi- (Fa\#)- Sol- La- Si- Re(\#) }
$$

Este tipo de melodía y de sucesión armónica son comunes en el repertorio andino popular y tradicional.

El texto de la tonada, en castellano, no menciona los hechos de Cajamarca, sino que describe poéticamente el acto de suspirar producto de una pena:

$$
\begin{aligned}
& \text { "Cuando la pena en el centro } \\
& \text { Se encuentra con el sentido } \\
& \text { Suspiro es aquel sonido } \\
& \text { Que resulta del encuentro". }
\end{aligned}
$$

Se trata de una cuarteta octosílaba con estructura ABBA, un tipo de cuarteta bastante común en la poesía y el canto popular de América. La relación con la música es silábica. A cada nota corresponde una sílaba y la métrica de la melodía no corresponde a la del texto, ya que el acento musical corresponde siempre a la última sílaba del verso: centró; sentidó; sonidó; encuentró. Esta es una característica de muchas canciones andinas actuales.

¿De qué habla el texto y qué relación podría tener este con los hechos de Cajamarca? Son numerosas en las crónicas coloniales las descripciones de la "pena de Atahualpa" durante su cautiverio y de las manifestaciones de dolor de las collas y nustas ${ }^{8}$, así como de toda su gente, frente a su muerte:

"Y de ver, y entender que he de morir tan presto, sin aver gozado de mis Reynos estoy triste: porque estas señales no se muestran, sino para anunciar grandes calamidades, muertes de Reyes, destrucción de imperios. Todo lo cual sospechava yo antes, viendome en cadenas de hierro, mas ahora me lo ha certificado de vera la cometa. Havras entendido la causa de mi tristeza, y la razon que tengo para tenerla" (Garcilaso de la Vega, 1617:25, Libro I, II parte, Cap. XXXIV).

"Fue tan grande el sentimiento que las mujeres y sirvientas hacían, que parecían rasgar las nubes con alaridos. Quisieran muchas matarse y enterrarse con él en la sepultura, mas no se les permitió. [...] Como las mujeres vieron que no se podían enterrar con su señor, se apartaban y se ahorcaban de sus mismos cabellos y con cordeles" (Pedro Cieza de León, 1553:Cap. LIV).

En este sentido debemos hacer notar que, al parecer, era común en el período incaico la manifestación del llanto ceremonial frente a posibles calamidades. Al respecto se puede señalar la siguiente descripción de Garcilaso de la Vega de los rituales realizados en ocasión de un eclipse lunar:

"Mandavan a los muchachos y niños que llorasen y diesen grandes voces y gritos, llamándola mama quilla (que es madre luna), rogándole que no se muriese” (2005:122).

${ }^{8}$ Las collas son las esposas del Inca y las ñustas las "princesas". 
Murúa relata la consulta al oráculo de los capitanes de Inca Yupanqui, y la reacción de ellos al conocer la futura llegada de los españoles:

"Refieren algunos indios viejos que estos capitanes, con Tupa Ynga Yupanqui, deseosos de saber qué les había de suceder en los tiempos venideros y qué sucesos vendrían a sus herederos, habiendo hecho grandes sacrificios y ayunos a su usanza, con llantos y ofrendas de animales" (1611:I, cap.90).

"Oída semejante respuesta, tristes y pensativos, habían hecho grandísimos llantos y muestras de dolor y sentimiento, por la persecución y trabajo que esperaban. Y por memoria de tan temerosa respuesta, compusieron un cantar triste y melancólico, a modo de endechas, el cual cantaban en las solemnidades y cosas que les sucedían de tristeza y pesar" (1611: I, cap. 90).

Lo interesante de esta última cita es que nos muestra cómo los pesares eran plasmados en música y cómo se podía perpetuar el recuerdo de hechos tan trascendentes con la práctica de estos últimos.

En el caso de nuestra tonada, los versos parecen referirse a la manifestación de un dolor provocado no por un miedo, miedo a la muerte o miedo a un futuro incierto, sino a un sentimiento de certeza: "la pena se encuentra con el sentido". En otras palabras, el sentimiento de pena encuentra su razón de ser en la claridad de los hechos futuros, estamos frente a la confirmación de un futuro trágico. El Inca Garcilaso de la Vega, en su Historia general del Perú, describe en diferentes momentos la convicción del Inca del fin de su Imperio:

"A este miedo se juntó no otro menos, que fue la profecía de su padre Huaina Capac, que después de sus días entrarían en sus reynos, gente nunca jamás vista ni ymaginadas que quitarían a sus hijos el imperio, trocarían su república, destruyría su idolatría. Paresciales al Rey Atahuallpa, que todo esto se iva ya cumpliendo muy apriessa" (Libro I, II parte Cap. XVII, 1617:13).

"Grandemente me huelgo varones divinos, que vos, y vuestros compañeros, ayays llegados en mis tiempos,á estas regiones tan apartadas, y que con vuestra venida ayays hecho verdaderas las adivinaciones, y pronosticos que nuestros mayores nos dexaron dellas: aun que mi animo antes devia entristecerce, porque tengo por cierto, que se han de cumplir, todas la demas cosas, que del fin deste nuestro Imperio, los antiguos dexaron pronosticadas, que avian de suceder en mis dias" (Libro I, II parte Cap. XX, 1617:15). "Solo os suplicamos tengays lástima de los mios, que me dolera mas la afición y la muerte de ellos que la mia. Con esto acabó el Inca, los suyos enternecidos de sus ultimas palabras, y de la pérdida del Imperio, que por tan cierto tenían, derramaron muchas lágrimas con grandes suspiros y gemidos, porque es asi, que fin lo que entonces dixo el Inca del fin de su Imperio, lo avia repetido antes muchas veces á los suyos" (Libro I, II parte Cap. XX, 1617:15) (cursiva agregada).

La línea del canto, el carácter melancólico de la melodía y el texto hacen pensar en un harawi o yaraví, un género poético-musical muy difundido hoy como en la Colonia. De posible origen incaico, ha sido practicado por hombres y mujeres -generalmente las mujeres cantando y los hombre tocando algún tipo de flautas-. Podía tratar diferentes argumentos y desempeñar distintas funciones sociales, desde los cantos ceremoniales agrarios hasta el canto de amor o del 
contexto trágico (Anna Gruszczynska 1995). Hoy en día los textos se refieren casi siempre a argumentos amorosos. Guamán Poma, en su Nueva corónica y buen gobierno, describe varias veces este género. Con respecto de la undécima colla dice lo siguiente:

"tenía mil indios rregosijadores: unos dansavan, otros baylava, otros cantavan con tambores y músicas, flautas pingollos, y tenía cantoras, Harawi, en su casa y fuera de ella para oyrlas dichas músicas que hacían Harawi” (1615 [1988]:119).

En otro paso Guamán Poma cuenta como cada Ayllu, división del Tawantinsuyo, tenía sus propios takis y harawi (1988:54). Nombra el harawi en diferentes situaciones de amor, como en el dibujo que muestra dos jóvenes tocando flautas en un peñasco y a dos mujeres cantando en un río. El texto dice "canciones i musica, aravi, pincollo, vanca” (1988:289) y describe también un harawi en un contexto ceremonial, por lo tanto, no amoroso, el "Aravi del Inca” (1615 [1988]:292).

Según Garcilaso, el harawi se componía de pocos y simples versos para poder ser recordado y reproducido por la flauta con facilidad. De todas maneras es evidente que el harawi, por lo menos hasta el siglo XVIII, podía referirse a diferentes situaciones, podía contar las "cosas del pasado" así como asuntos amorosos. Aparentemente lo que definía el género no era tanto el argumento del texto, sino el "tono" musical de la canción (Gruszczynska 1995:90-91).

Según el estudioso Raúl Porras Barrenechea, el yaraví, descendiente del incaico harawi, se definió a lo largo del siglo XVIII como canción "enlutada y llorosa”. El Mercurio Peruano, en el año 1791, dedica varias páginas a la descripción de este género:

"Una comprobación fundamental surge del análisis de los escritores del Mercurio, particularmente de la interpretación de Sicramio, que fue el disertante: lo esencial en el yaraví, lo que le presta todo su patetismo, su melancolía incurable, es la música. La poesía cantará olvidos y tristezas del amor, tiranías del ser querido, males de ausencia y aun figuras mitológicas, en endechas castellanas de cinco o de ocho sílabas, pero los versos se han de acomodar a la tonada musical y ésta es, dice el comentarista 'la excelencia más noble de los yaravíes'. La asociación musical es la que produce el fenómeno romántico de las lágrimas. '¿Qué oídos -dice el escritor mercurial- no quedan arrebatados de su influencia? ¿Qué ojos que no se inunden de llanto? ¿Qué persona que no se conmueva sólo con el oír tocar su aire en un mero instrumento?' Y responde con el testimonio desbordante de su propia emoción: 'Por lo que a mí toca, confieso con ingenuidad que cuando oigo estas canciones, se abate mi espíritu, se acongoja el ánimo, el corazón se entristece, los sonidos se encalman y el llanto humedece mis ojos. La finalidad del yaraví está lograda, hacer llorar" (Porras Barrenechea 1999).

De esta descripción se desprenden varios elementos interesantes. Lo primero es que el argumento no es necesariamente amoroso. Lo segundo es la importancia fundamental de la música en expresar el sentimiento, ya que es posible tocar un yaraví solamente instrumental para evocar una emoción particular sin recurrir al texto. Este hecho nos recuerda la definición de "tono" incaico, como un conjunto de elementos musicales rítmico-melódicos, asociados a determinadas situaciones 
de manera que, como enunciaba Garcilaso de la Vega, "no podian decir dos canciones diferentes por la misma tonada”.

La segunda tonada: "E. 191 Adagio tonada el Tuppamaro de caxamarca" (ver ejemplo $\mathrm{N}^{\circ} 2$ ), consta de una introducción instrumental, del canto propiamente tal y de una coda instrumental. Esta última es casi idéntica a la introducción, excepto por una variante en el tresillo del tercer compás -un Sol en la introducción, un La en la coda. Como en la primera tonada el tiempo es en dos cuartos con el uso de tresillos. La tonada está dividida en dos partes con repeticiones, de dos frases cada una. La primera y tercera frases terminan en un calderón. Este último es un recurso musical expresivo -se crea una suspensión del pulso- típico del yaraví.
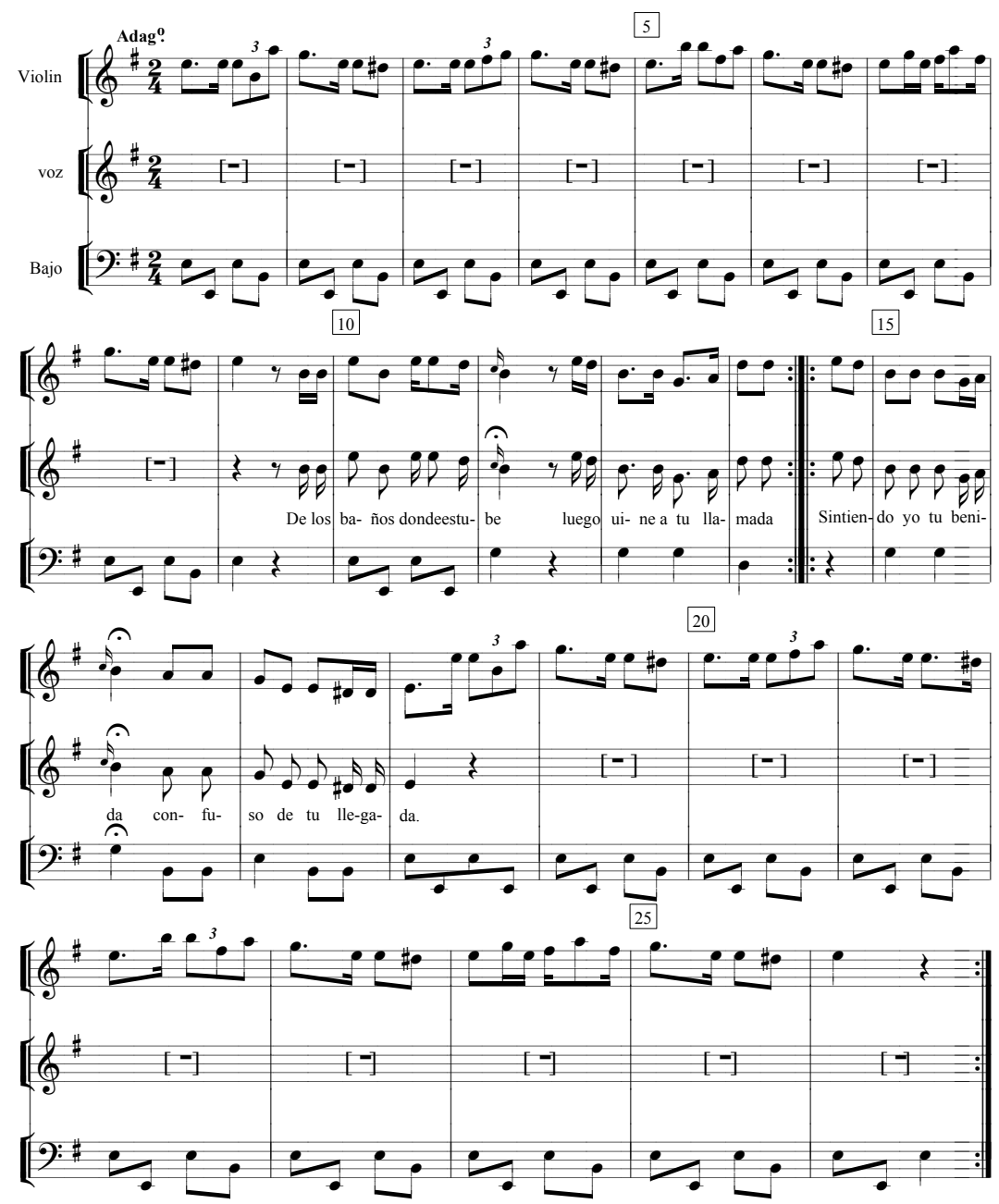

Ej. No 2. Tonada el tuppamaro de Caxamarca. Martínez Compañón, II, fol. 191 
La pieza tiene un sostenido (\#) en la armadura y, como la primera, está escrita en una aparente tonalidad de Mi menor, con un pasaje al tercer grado mayor (Sol). La escala de la introducción instrumental es una escala de Mi menor con el Re\# (sensible) y sin el Do (sexto grado). La escala del canto es absolutamente pentatónica: Mi- Sol- La- Si- Re (\#).

Los acordes son los mismos que en el primer caso: Mi menor- Si-Sol-Re.

Se puede afirmar entonces que el contexto musical de las dos tonadas, esto es, la escala musical, la armonía y el carácter de la melodía, vendría a ser el mismo. Las dos tonadas podrían inspirarse en el mismo modelo "compositivo", es decir, como ya se ha dicho, en el mismo tono.

El texto es en castellano y hace referencia a los hechos de Cajamarca. De hecho describe sucintamente en una sola cuarteta de versos octonarios, la espera y el encuentro de Atahualpa con los españoles:

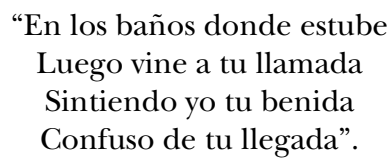

Esta manera de contar la acción, breve y resumida, aparece como similar a un ejemplo de harawi que Garcilaso describe y traduce del quechua (2005:131).

$$
\begin{aligned}
& \text { "Al cantico } \\
& \text { Dormirás, } \\
& \text { Media noche } \\
& \text { Yo vendré". }
\end{aligned}
$$

Cada verso de la cuarteta de nuestra tonada resume la acción en un "cuadro" o imagen: la estadía de Atahualpa en los baños; la respuesta de Atahualpa a la "llamada" de los españoles, es decir, la llegada de Atahualpa a Cajamarca; la llegada a Cajamarca de los españoles; el encuentro con los españoles. Los cuatros versos están en primera persona. Se pueden graficar en cuatros acciones: estar; venir; sentir y confundirse. Sin embargo, no se puede negar que un sentimiento de espera ansiosa recorre la cuarteta entera. Concretamente la "confusión del encuentro" del último verso tiñe de un trágico significado las acciones de los tres primeros versos, ya que la "confusión" se puede entender como asombro por la acción inesperada de los españoles. La sorpresa y el asombro referidos al momento de la captura de Atahualpa en Cajamarca son dos temas recurrentes en las crónicas coloniales. En Garcilaso un completo capítulo está dedicado al "Gran alboroto que huvo entre Indios y Españoles" (Libro I, II parte Cap. XXV, 1617:19). Otros dos capítulos se refieren a la captura de Atahualpa (Libro I, II parte Cap. XXVII, 1617:21). Garcilaso pasa revista a otros autores, como López de Gómara y Blas Valera, que confirmarían su versión, la sorpresiva furia de los españoles y la poca resistencia de los indios: 
"Los Españoles de acavallo salieron de sus puestos, yá toda furia arremetieron con los escuadrones de los Indios, y alancearon todos lo que pudieron sin hallar resistencia" (Libro I, II parte Cap. XXVII, 1617: 21).

"No huvo Indio que peleasse, aunque todos tenian sus armas, cosa bien notable contra sus fieros, y costumbre de guerra, no pelearon porque no les fue mandado ni se le hizo la señal, que concertaron para ello, (si menester fuesse), con el grandissimo rebato, y sobresalto que les dieron porque se cortaron todos de puro miedo, y ruido, que hicieron aun mismo tiempo las trompetas, los arcabuces, y artilleria, y los cavallos que llevavan pretales de cascaveles: para los espantar" (Libro I, II parte Cap. XXVI, 1617: 21).

Otros autores se refieren a la captura de Atahualpa en los mismos términos:

"Oyda esta dicha nueva se espantó el dicho Ynga y le dixo: “Que nueva me traes, mal mensaje!" Y ancí quedaron espantados con la nueva nunca oyda” (Guamán Poma 1980:354). "Y ací luego comensaron los caballeros y despararon sus alcabuses y dieron la escaramusa y los dichos soldados a matar yndios como hormiga. Y de espanto de arcabuces y rruydo de cascabeles y de las armas e de ver primer hombre jamás visto, de estar lleno de yndios la plasa de Caxamarca y se mataron entre ellos" (Guamán Poma de Ayala, 1615 [1988]:358).

"Pizarro como entendió lo que le había pasado a fray Vicente con Atabalipa, mirando cómo no era tiempo de más aguardar, alzó una toalla señal para mover contra los indios, soltó Candía los tiros, cosa nueva para ellos y de espanto, mas fueron los caballos, que diciendo los caballeros grandes voces "Santiago, Santiago", salieron de los aposentos contra los enemigos; los cuales, sin usar de los ardides que tenían pensados, se quedaron hechos "personajes"; no pelearon, mas buscaron por donde huir" (Pedro Cieza de León, 1553: Cap. XLV).

"Lo cual dando voces el padre Fr. Vicente de Valverde y diciendo: ¡cristianos, los evangelios de Dios por tierra! arremetió don Francisco Pizarro con los suyos. Y llegando a las andas donde estaba Atao Hualpa, embistió con él y lo derribó dellas. Visto por los indios a su rey en el suelo caído y que los españoles meneaban las manos y se aprovechaban de sus armas y especial de los arcabuces, nunca hasta allí vistos ni oídos dellos, parecióles que rayos de fuego bajaban del cielo a abrasarlos, y como venían sin armas ningunas, como está dicho, todos se pusieron en huida, dejando al desdichado de su rey y Señor desamparado y en poder de los españoles, que contentísimos del buen suceso y tan sin peligro ni muerte de ninguno, le prendieron y llevaron consigo a Caja Marca" (Fray Martín de Murúa 1611: Libro I, Cap. LIX).

Esta es una posible lectura de los versos, una lectura cronológica de los hechos, pero no es la única. Otra posible lectura podría ser no cronológica. Los cuatro versos se refieren en este caso no a acciones distribuidas en un eje temporal antecedente-consecuente, sino a una serie de hechos y sentimientos ligados al tema general de la llegada de los españoles a las costas peruanas. Una situación global compuesta de hechos significativos para el desenlace final, la suerte de Atahualpa y de su imperio, que se pueden graficar en la estadía de Atahualpa en los baños; las diferentes embajadas de los españoles; la noticia de la llegada de los españoles; la confusión generada por la noticia de un evento nuevo y extraordinario, la llegada de personajes "nunca antes vistos". 
De cualquiera interpretación de la cuarteta mencionada anteriormente, es interesante subrayar el carácter polisémico de la misma. Al estar justamente fragmentada en acciones o estados de alguna manera autónomos, nos entrega la experiencia, en solo cuatro versos, de los sentimientos de agitación, inquietud y asombro asociados al tema principal o al contexto macro de los hechos específicos de Cajamarca: la llegada de los españoles y el fin del Imperio incaico.

Esta segunda "Tonada el tupamaro de caxamarca" comparte la hoja de transcripción con otra pieza musical: "E. 191, Magestuoso Cachua la Despedida de Guamachuco" (ver ejemplo $\mathrm{N}^{\circ}$ 3). Llama la atención esta improvisada parsimonia del transcriptor y parece improbable que sea un simple hecho casual. En general -con la excepción de dos danzas muy breves- a cada pieza musical le corresponde una hoja. Analizamos esta breve pieza musical, junto con otra tonada "la brugita para cantar de Guamachuco", solamente para subrayar cómo estas representaciones podían convertirse en transmisión de saberes históricos andinos, en la época colonial. El hecho de que esta cachua se encuentre en la misma hoja de transcripción, nos hace suponer que sea parte del mismo objeto observado.

Actualmente la cachua es un baile cantado, realizado con ocasión de la época de lluvia, entre epifanía y carnaval, por todas las poblaciones del altiplano andino. El baile es una rueda de hombres y mujeres tomados de la mano. En la época colonial la cachua se bailaba con ocasión de grandes fiestas y es descrita por Cobo como baile de hombres y mujeres en rueda (Gruszczynska 1995:100-102).

La pieza musical consta de una introducción instrumental de 11 compases de $2 / 4$ y de una parte cantada de 10 compases. Contiene dos sostenidos en la armadura y se mueve en la tonalidad de Re mayor. La melodía de la introducción abarca la escala de Re sin el sexto grado $(\mathrm{Si})$, con una extensión de La a Sol. La melodía del canto se mueve en un intervalo de sexta de Re a Si. La pieza tiene un carácter en el que sobresale la figura de la síncopa. La armonía se mueve entre el I, V y IV grado de la escala de Re: Re- La-Sol. El tono menor está completamente ausente.

La cachua "La despedida de Guamachuco" nos parece una pieza muy diferente a las analizadas hasta ahora. El texto es una cuarteta en versos octonarios y dice lo siguiente:

"De bronse devo de ser

De diamante o de rubi,

$\mathrm{O}$ a mi me teme la muerte

O no ay muerte para mi”.

El Inca Atahualpa después de años de luchas fratricidas se encuentra triunfante en Huamachuco, alistándose para partir rumbo al Cuzco a recibir las insignias imperiales. Es posible que esta cachua "Majestuosa", como reza la indicación en la partitura, con aires de marcha triunfal describa el momento en que Atahualpa, en el ápice de su gloria, recibe la noticia de que unos "barbudos" aguardan en Cajamarca. El texto es decidor, es un desafío a la muerte, Atahualpa ya demostró poder sobrevivir a los ataques de su hermano y ya una vez se escapó del cautiverio y de una muerte segura, bajo la forma de una culebra. Los cronistas relatan: 

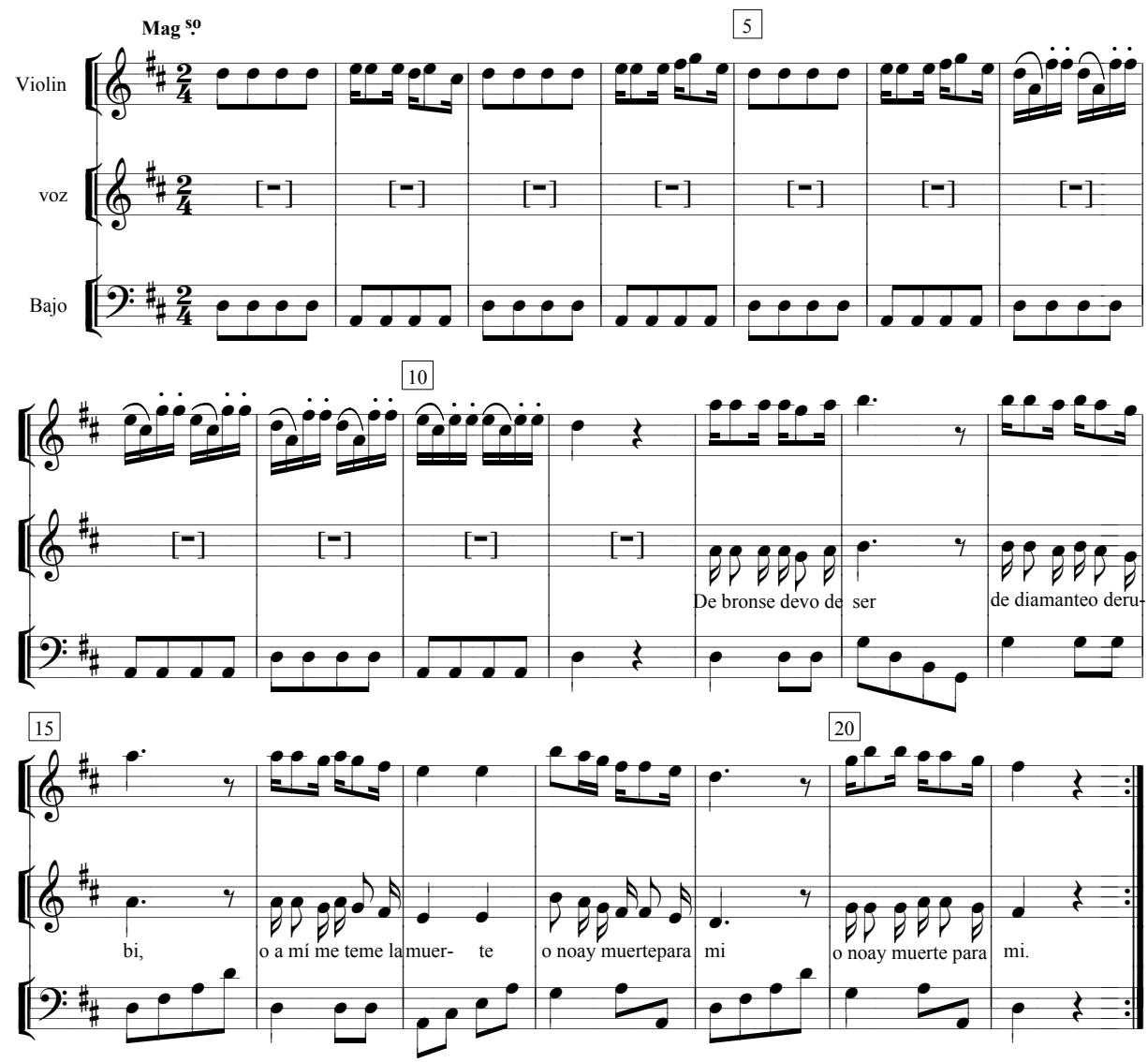

Ej. Nº 3. Cachua la despedida de Guamachuco. Martínez Compañón, II, fol. E. 191

"El Gobernador [...] mando llamar á un cacique, del cual supo que Atabalipa estaba delante de Caxamalca, en Guamachuco, con mucha gente de guerra, que serian cincuenta mil hombres" (Francisco de Jerez 1534).

Esta cachua precede, en la hoja, la segunda tonada el Tupamaro de Caxamarca. Se trata efectivamente de Atahualpa, quien después de enterarse de la llegada de los españoles se dirige desde Huamachuco a Cajamarca.

Otra tonada: "E. 190 Allegro tonada la brugita para cantar de Guamachuco" (ver ejemplo $\mathrm{N}^{\circ} 4$ ), podría tener relación con la estadía de Atahualpa en Huamachuco. Esta tonada consta de una introducción instrumental y de una parte cantada. La melodía instrumental está en una escala de Re menor sin el sexto grado Si bemol. La parte cantada se construye en la escala completa de Re menor. La aparente tonalidad de Re menor se desplaza rápidamente a su relativo mayor Fa. La estructura melódico-armónica es la misma de las primeras tres tonadas. El 
canto es muy breve de carácter un poco perentorio y la introducción tiene un cierto tono lúgubre.

El texto es una cuarteta de versos octosílabos:

"Desengañado esta ya

Ojala no lo estuviera

Pues engañado viviera

Con un quisá no será”.
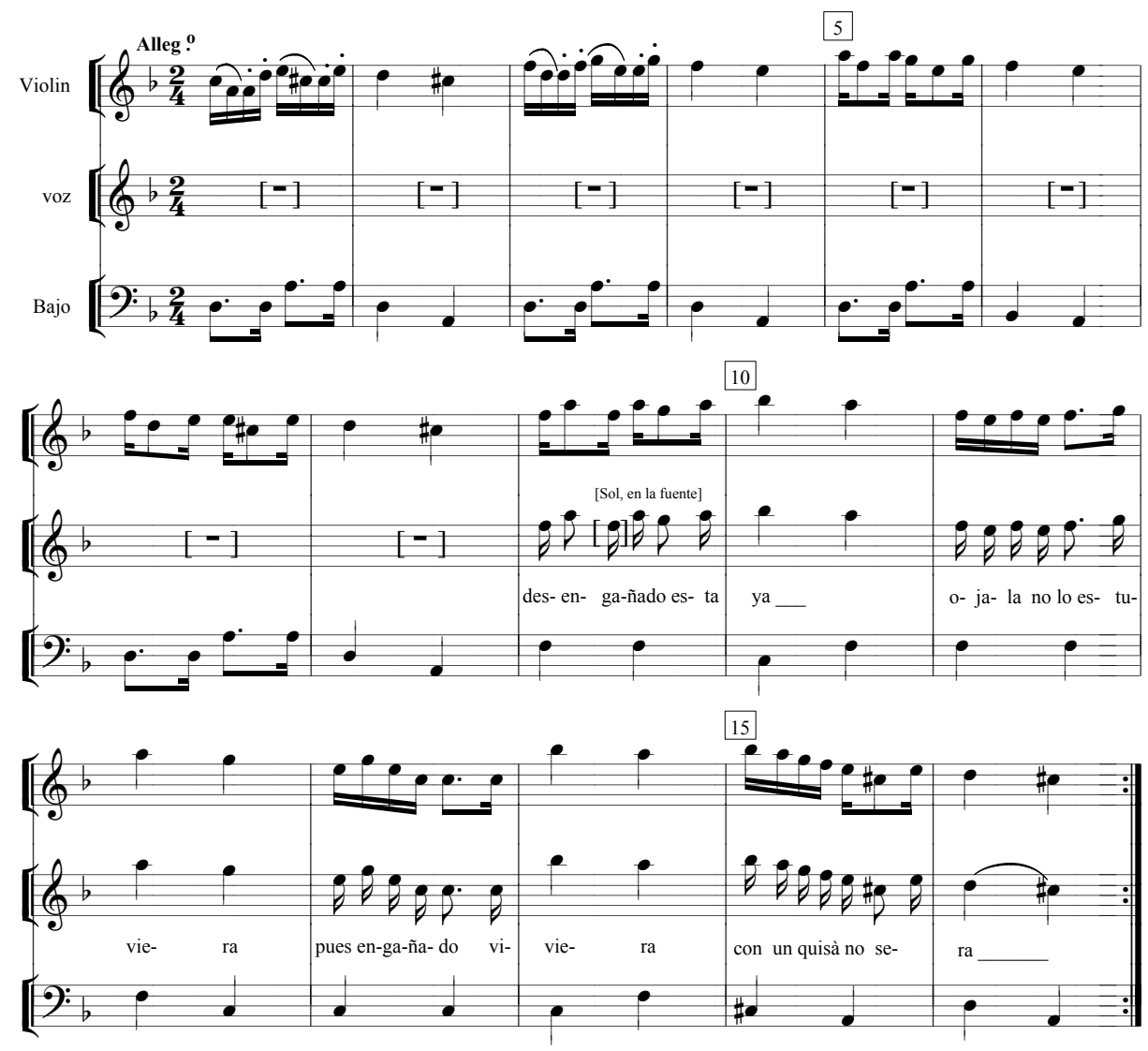

Ej. N4. Tonada la brugita para cantar de Guamachuco. Martínez Compañón, II, fol. E.190

¿"La brugita” podría ser el oráculo de Huamachuco? Según Raúl Porra Barrenechea (1999:6), Atahualpa destruye los ídolos de Huamachuco y mata al sacerdote decapitándolo. Al parecer la Huaca Catequil, consultada por el Inca, entregaría un mal presagio, provocando sus iras. El término brujita podría ser simplemente una occidentalización de la figura del oráculo andino.

Es posible entonces que el título y texto de estos dos cantos narren algunos hechos relacionados con la estadía de Atahualpa en Huamachuco. De ser así 
estas piezas musicales podrían ser parte de una representación teatral del fin de Atahualpa. La existencia de estas dos piezas en el códice apoya nuestra hipótesis de que efectivamente el obispo Martínez Compañón y sus acompañantes, dibujantes y transcriptores, fueron testigos de una representación de este tipo.

El tema de la "brugita" nos recuerda la importancia de la figura del oráculo en la cultura andina. De hecho, como pudimos ver respecto del análisis de la primera tonada, el presagio del fin del Imperio incaico ocupa un amplio espacio en las crónicas coloniales. El sueño premonitor y la consulta al oráculo constituyen también el tema de una de las láminas: "Danza de la degollación del Inca". Estas consideraciones hacen suponer que la premonición pudiera ser un hecho central en una posible representación del fin de Atahualpa.

La estructura musical de la tonada, "E. 191 el Tupamaro de Caxamarca", nos permite encontrar un posible vínculo con otra tonada del mismo códice, que no tendría aparente relación con el tema de Atahualpa. Se trata de la tonada "E. 187, Andantino Tonada El Diamante, para baylar cantando de chachapoyas" (ver ejemplo $\mathrm{N}^{\circ} 5$ ). De hecho estas dos tonadas parecen ser variantes de un mismo modelo musical.

El título de la tonada "El Diamante, para baylar cantando de chachapoyas" indica claramente la presencia del baile. En las crónicas coloniales se hace frecuentemente referencia al "bailar cantando" de las poblaciones andinas:

"Tenían otra manera estas gentes de memorar las cosas pasadas y antiguas y esto es en sus cantares y bayles que ellos llaman Areytos [o Taquis] que es lo mesmo que nosotros llamamos baylar cantando" (Fernández de Oviedo 1547: Libro V, cap. I).

"Tañen diversos instrumentos para estas danzas: unas como flautillas o cañutillos; otros como atambores; otros como caracoles; lo más ordinario es en voz, cantar todos, yendo uno o dos diciendo sus poesías y acudiendo los demás a responder con el pie de la copla. Algunos de estos romances eran muy artificiosos, y contenían historia; otros eran llenos de superstición; otros eran puros disparates. Los nuestros, que andan entre ellos, han probado ponelles las cosas de nuestra santa fe, en su modo de canto, y es cosa grande de provecho que se halla, porque con el gusto del canto y tonada, están días enteros oyendo y repitiendo sin cansarse. También han puesto en su lengua, composiciones y tonadas nuestras, como de octavas, y canciones de romances, de redondillas, y es maravilla cuán bien las toman los indios, y cuánto gustan. Es cierto gran medio este y muy necesario, para esta gente. En el Pirú llamaban estos bailes, comúnmente taqui” (José de Acosta, 1590: cap. XXVIII).

"Considero que ambos [cantares y taqui], como lo indican Cobo y González Holguín, eran una misma cosa: una conjugación de danza y canto donde casi se teatralizaban los acontecimientos" (Burgas 2005:210-211).

Guamán Poma nombra y describe varias veces la acción del bailar cantando en las diferentes fiestas de los cuatros Suyos (1615 [1988]:288-301). En los dibujos que ilustran sus comentarios, las figuras se muestran siempre en movimiento, trátese de baile o de simple desplazamiento. 


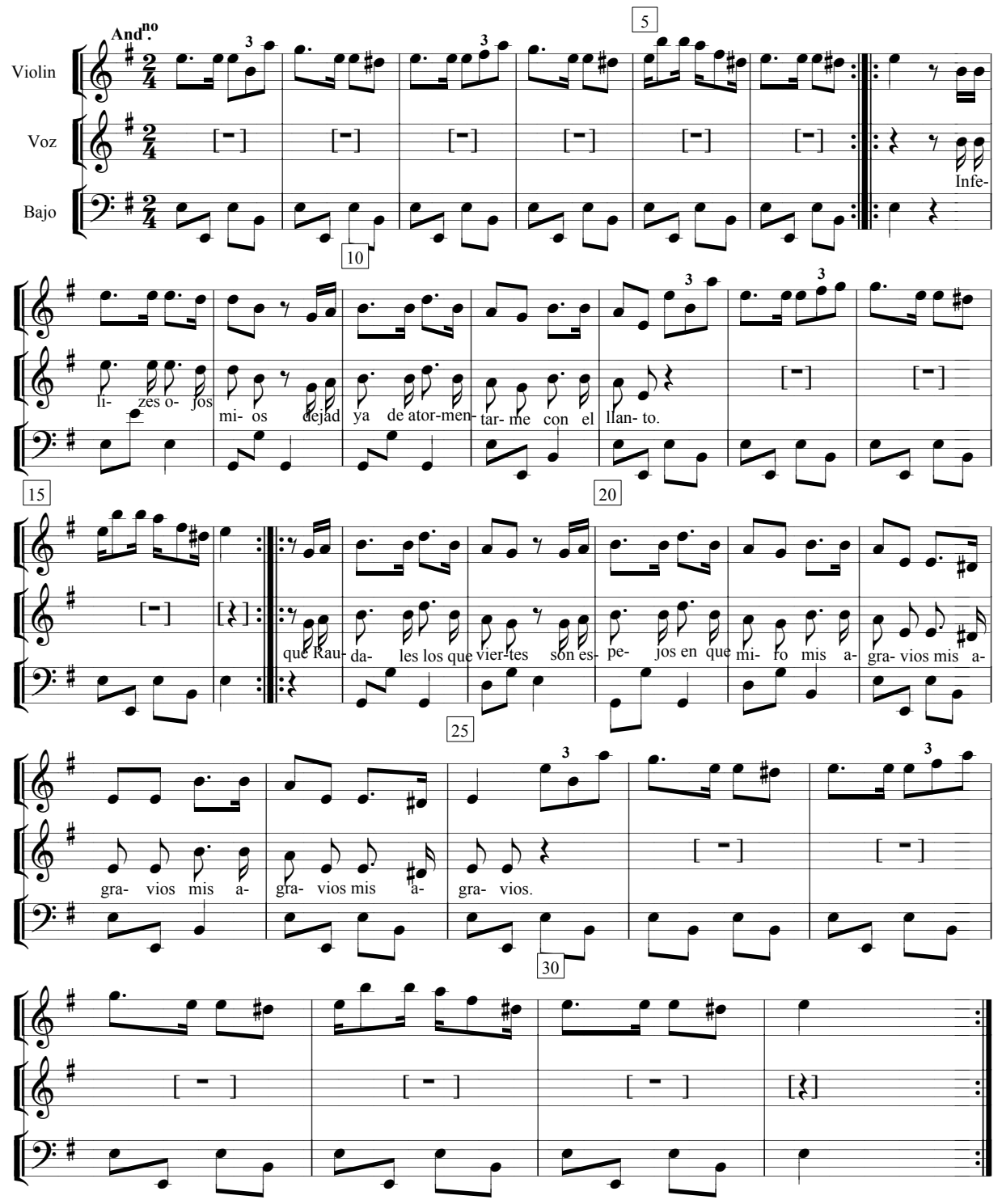

Ej. $\mathrm{N}^{\circ}$ 5. Tonada del Diamante para baylar cantando de chachapoyas. Martínez Compañón, II, fol. E.187

En este sentido se puede intuir por las descripciones de los cronistas coloniales, que la música iba siempre acompañada por el movimiento, práctica que se puede observar todavía en las performances musicales de las poblaciones andinas. Además, las diferentes expresiones culturales como las poesías, danzas y músicas, se enmarcaban en un contexto ceremonial. Los escritos de Guamán Poma son un claro ejemplo de este hecho: 
"Con los escritos de Guamán Poma se reubica el discurso andino Quechua. Un texto está siempre precedido del ritual que los acompaña, no son enunciados letrados, sino constituye un tejido discursivo cuya unicidad dialógica incorpora voz y cuerpo, habla y espacio, lengua y tiempo, palabra y cosmovisión, lenguajes que le dan forma" (Espino Relucé 2006: 95).

Sobre la representación de la captura y muerte de Atahualpa en la actualidad, Manuel Burgas afirma:

"Los estudios sobre esta misma representación [representación de la captura y muerte de Atahualpa] en América Central y México son también abundantes; todas las descripciones parecen coincidir en presentarlas como diversas variantes de una danza única [...] En el Perú central, la región que hemos estudiado, este drama popular nunca lo hemos encontrado como representación teatral ni casi teatral, sino fundamentalmente como danzas realizadas por comparsas que desarrollan, con la intervención de toda la población, el argumento de la tragedia de Atahuallpa dentro de las fiestas patronales" (2005:51-52).

En todas las representaciones documentadas las pallas ${ }^{9}$ son las encargadas de acompañar la acción teatral con cantos y bailes. Richard Schaedel registra, en 1949, una representación de la muerte del Inca, en ocasión de la fiesta de la Virgen de la Puerta de Otuzco, en el norte del Perú. En ella participan grupos de ñustas acompañando al Inca con sus bailes y cantos. De hecho Schaedel describe esta manifestación como una danza (ver lámina $\mathrm{N}^{\mathrm{o}} 1$ ).

Manuel Burgas (2005: 89), al referirse a una escenificación actual del IncaCapitán, en Mangas, Chilcas y Chiquián, en los Andes centrales, describe la constante presencia de las pallas que acompañan al Inca en toda la acción con sus cantos y bailes. El rol de las pallas en estas representaciones se trataría, según la apreciación de Burgas, de un "canto triste, casi un llanto".

Asimismo las dos láminas de Martínez Compañón, que muestran dos momentos de la representación de la captura y muerte de Atahualpa, tienen por título "Danza de la muerte del Inca". La lámina E 172 (ver lámina $\mathrm{N}^{\circ}$ 2) representa el sueño de Atahualpa, el Inca está sentado en su "trono" dorado con sus atuendos imperiales. A su alrededor se encuentran las ñustas y el hechicero que está soñando y consultando sus oráculos.

La segunda lámina, E 173 (ver lámina $\mathrm{N}^{\circ}$ 3), muestra el momento mismo de la decapitación del Inca. En esta segunda ilustración cambia la perspectiva. Desaparece la construcción detrás del trono que creaba una cornisa escenográfica al primer dibujo, se ve el paisaje externo con el trono en una esquina, al centro el camino por donde llegan y se van los españoles en el medio de ríos y montañas. El Inca, ya decapitado, es acompañado solamente por una mujer que llora y los españoles están vestidos con trajes de finales del siglo XVIII, es decir, contemporáneos a la

${ }^{9}$ Las pallas son conjuntos de mujeres que cantan y bailan en las fiestas de los santos patronos. En general visten ricos vestidos que recuerdan las collas incaicas, en el códice Martínez Compañón se encuentran dibujadas en varias láminas. 


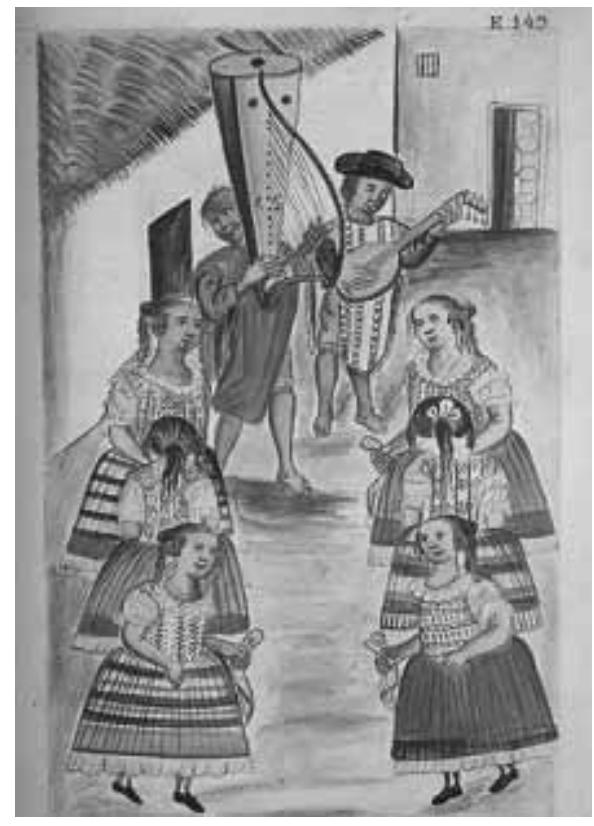

Lámina $\mathrm{N}^{\mathrm{o}} 1$

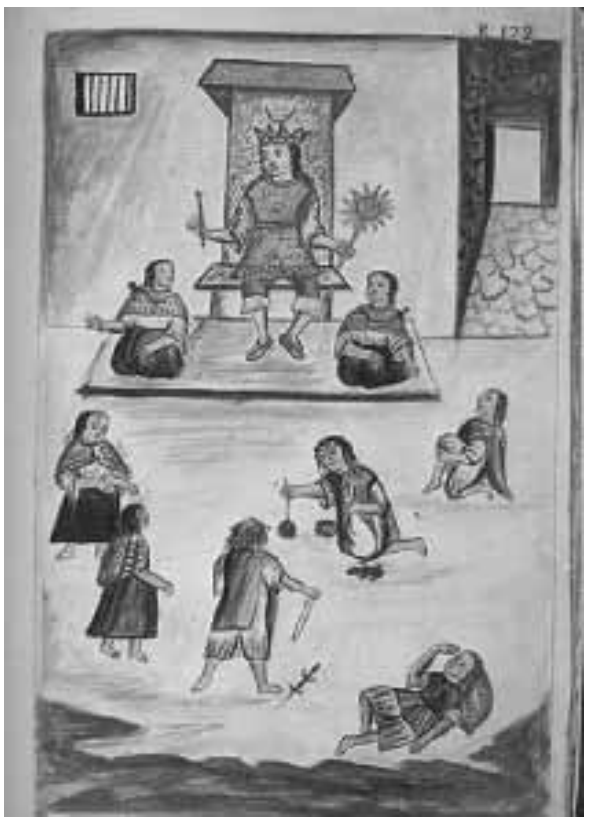

Lámina $\mathrm{N}^{\circ} 2$

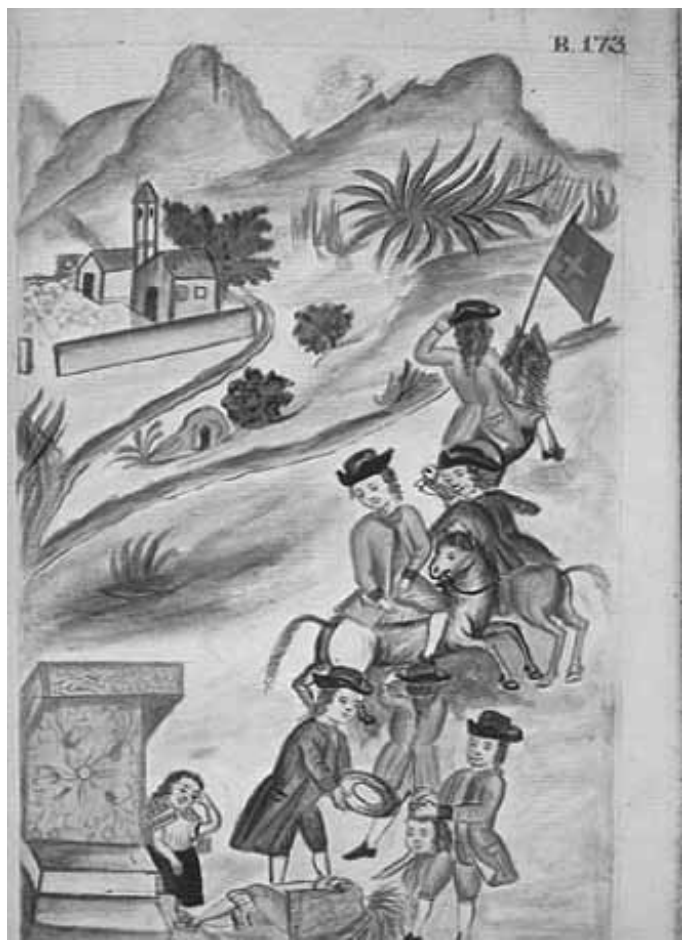

Lámina $\mathrm{N}^{\circ} 3$ 
confección de la lámina. Toda la escena repropone el imaginario de la muerte de Atahualpa, así como fue descrita en varias imágenes a lo largo de la Colonia.

En nuestra opinión, existen dos posibilidades de lectura de estas láminas asociadas a danzas. La primera es que se refieran al contexto general de la representación, es decir, una situación performantica en la cual las danzas y los desplazamientos coreográficos sean preeminentes, o acompañen constantemente la acción. La segunda posibilidad es que el dibujante haya extrapolado de una coreografía el tema central de la performance, y haya usado para esto los tópicos culturalmente definidos y asociados a la muerte de Atahualpa. Por lo tanto, las dos láminas estarían de alguna manera asociadas al evento presenciado sin ser necesariamente parte de este. Serían la imagen gráfica de dos momentos centrales en la representación del drama: el sueño del Inca, es decir, la premonición del fin de su imperio y su decapitación. De todas maneras el hecho que las dos láminas se titulen "danza" hace pensar en la persistencia de esta forma de expresión cultural en un evento como la representación de la muerte de Atahualpa.

Del punto de vista del análisis musical, podemos decir que la tonada El Diamante es una versión de la misma tonada E. 191 (b) El Tupamaro de Caxamarca anteriormente descrita. Las variantes en la parte instrumental son mínimas: la introducción y la coda son de seis compases en vez de ocho, pero se conserva el mismo giro melódico. En el caso del canto las variantes son mayores, pero la estructura del canto es la misma. Existe coincidencia en las primeras frases de ambas; la segunda frase en el Tupamaro termina en Sol y en el Diamante se conserva el Mi menor. La segunda parte de ambas empieza en Sol y termina con la misma frase para ambas en Mi menor. Ambas contienen un interludio que separa las dos partes y que es la repetición de la introducción, incompleta en el caso de El Diamante.

A pesar de que no se hace referencia a los hechos de Cajamarca, ni en el título, ni en el texto, consideramos la base de lo señalado acerca del sistema de tonos incaicos que las dos tonadas, El Tupamaro y El Diamante, tienen relación entre sí en cuanto al contenido y a la situación representada. De ser así podemos suponer que en una posible representación teatral, la misma melodía podría referirse al sentimiento de un mismo personaje, es decir, a un mismo personaje en una misma situación emocional. Si en la primera es el Inca quien habla en primera persona, podemos pensar que en la segunda se repita la misma situación. En este caso el texto en castellano habla del llanto:

$$
\begin{aligned}
& \text { "Infelizes ojos mios } \\
& \text { Dejad ya de atormentarme } \\
& \text { con el llanto. } \\
& \text { Que raudale los que viertes } \\
& \text { Son espejos en que miro } \\
& \text { Mis agravios". }
\end{aligned}
$$

Se trata de cuatro versos octonarios, intercalados por dos versos de cuatro sílabas. 
Evidentemente lo que se ha señalado respecto del género musical para la primera tonada, se aplica también a las otras dos: el segundo Tupamaro y El Diamante. En el caso de El Diamante la relación con el género del yaraví es aún más evidente por el carácter realmente melancólico y "lloroso". El sentimiento de asombro descrito en la Tonada el Tupamaro E 191 (b), se traduce en lágrimas desesperadas en El Diamante. En caso de que lo afirmado respecto de los tonos incaicos se pueda aplicar aquí, la sola interpretación instrumental de esta melodía podría llamar a la memoria la tragedia de Atahualpa en toda su magnitud. Para entender a cabalidad la imagen que estas dos tonadas podrían evocar en un posible oyente "andino" del siglo XVIII, buscaremos los antecedentes de este "llanto incaico".

Encontramos referencia al llanto del Inca en diferentes crónicas y en poesías en quechua del teatro popular. En la siguiente descripción de Guamán Poma (1615 [1988]:360) de la captura de Atahualpa, el mismo Inca llora su suerte. Se puede apreciar además cómo la manifestación del dolor da pie a la composición de un harawi:

"Y cómo se vido tan mal tratamiento y daño y rrobo tubo muy gran pena y tristeza en su corazón y lloró y no comió. Como vido llorar a la señora coya, lloró y de su parte hubo grandes llantos en la ciudad. De los yndios cantava desta suerte:

$$
\begin{gathered}
\text { "Aray araui! ¿Aray aravi! } \\
\text { ¿Podrá este enemigo malvado, reina, } \\
\text { derrotarnos, darnos pesadumbre? } \\
\text { ¿No, reina! Vamos a morir todas a una. } \\
\text { ¿Qué no nos alcanze la desgracia! } \\
\text { Las lágrimas caen como lluvia por sí solas. } \\
\text { ¿Podrías tú, reina, ser tal?”. }
\end{gathered}
$$

En la Tragedia del fin de Atahualpa, drama en quechua recogido en Chayanta, fechado 1871, traducido y publicado por Jesús Lara en 1957, el coro de las ñustas canta la muerte del Inca (Bendezú, s/f: 188):

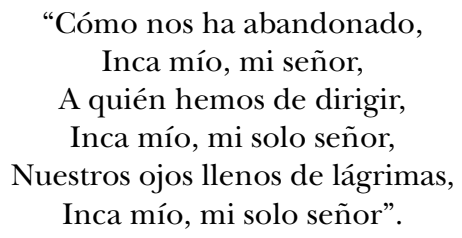

Otro lamento en honor a la muerte de Atahualpa es considerado por Jesús Lara (1960:48) como un poema paradigmático del género funerario. En este poema aparece en muchas de las estrofas el tema de las lágrimas derramadas por las nustas y por todos los presentes. Una estrofa en particular nos llama la atención por tener similitud con nuestra tonada en cuanto a la metáfora de las lágrimas como espejo que refleja la tragedia: 


\section{"Lágrimas de sangre arrancadas \\ De la ventura ida, En vuestro espejo retratad \\ Su cadáver" (1960:191).}

Gruszczynska (1995: 40-42) describe el llanto ceremonial en ocasión del "pacarico", ceremonia realizada en situaciones como el luto y el entierro. "Los elementos principales de la ceremonia de Pacarico era el pacarico mismo (la vela), el sasechico (la abstención ritual de sal y de ají) y uacachico (realización de lamentos rituales)". La música que acompañaba estas ceremonias eran tonos tristes. Al bailar y danzar, los participantes lloraban.

La presencia del llanto ceremonial acompañado de cantos y danzas es un dato de especial importancia para nuestro trabajo. Indica que la presencia de "tonos" específicos para las ocasiones relativas a la muerte, y en especial la muerte de algún Inca, constituye un hecho que podía tomar dimensiones de participación masivas. Si pensamos en la teatralización de un hecho tan trascendente para la cultura andina, como lo es la captura y el fin de Atahualpa y de su imperio, es probable que en estas representaciones se encuentren cantos y bailes cuyo contenido sea el llanto ceremonial. En este sentido la presencia de estos cantos cobra un significado más profundo, ya que no estaríamos en presencia de la representación subjetiva de la emoción, sino que se trataría en este caso de la elaboración culturalmente definida y representada de una emoción colectiva.

Podemos afirmar, entonces, que la tonada "El Diamante" no habla simplemente de la tristeza o del luto en sentido genérico, sino que se remite al momento específico del llanto colectivo ceremonial. Al llanto del Inca se le suma el llanto de todo su pueblo.

Esta tonada contiene algo peculiar en el título: la palabra diamante no aparece en ninguno de los cuatro versos. Los títulos de las tonadas, cachuas y bailes del códice Martínez Compañón siempre indican el género y el nombre propio de la pieza. En general contienen palabras nombradas en los textos de las canciones, como es el caso de Tonada La lata; Tonada el Palomo; Cachuíta de La Montaña; Bayle del Chimo; etc. En otros casos, como por ejemplo las dos Tonadas Tupamaro de Caxamarca y las dos Cachuas al nacimiento de Cristo Nuestro Señor, los títulos se refieren al argumento del texto y al contexto de interpretación, en este caso a los hechos de Cajamarca y a las adoraciones de Navidad. En tal sentido el transcriptor tuvo siempre el cuidado de ubicar al posible lector-intérprete haciendo referencia en el título a algo coherente con el género, el argumento o el contexto de los cantos.

Por esta razón resulta extraña la presencia del diamante en el título de esta tonada. Si en el texto no se hace referencia a ningún diamante, queda solo la posibilidad de que el "diamante" se refiera a algo contextual y conocido por los ejecutores-auditores de la época ¿Qué relación podría tener esta piedra preciosa con la muerte de Atahualpa? Hasta este punto podríamos todavía tener dudas respecto del argumento de la tonada, si es parte o no de una posible representación sobre la muerte de Atahualpa, ya que sus versos "llorosos" simplemente podrían 
tener relación con una desafortunada situación amorosa. No obstante, buscando en los textos de las representaciones teatrales de la captura y muerte de Atahualpa, encontramos una referencia interesante, aunque única, de la relación del diamante con el Inca en la Tragedia del fin de Atahualpa ya mencionada, publicada por Jesús Lara en 1954 y fechada Chayanta 1871. Los versos relatan el saludo de Atahualpa a su hijo Inkay Churin. El Inca, antes de morir, entrega a su hijo "un luminoso diamante":

\author{
“Ay, hijo mío! ¡y qué \\ voy a dejarte a ti? \\ Te dejaré este claro, \\ Este luminoso diamante, \\ Llevandolo contigo \\ Aléjate de aquí \\ Y refúgiate en Willkapanpa [...]" \\ (Bendezú, s/f:182).
}

Respecto de la simbología del diamante, no tenemos referencias del significado de esta piedra para las poblaciones andinas, sí sabemos que en la cultura occidental el diamante tiene nobles y sagradas connotaciones: Para los antiguos griegos y romanos, los diamantes eran considerados las lágrimas de los dioses o la luz de las estrellas. La palabra deriva del griego "adamas" que significa inexpugnable o invencible. A lo largo de todo el Medievo y Renacimiento los diamantes daban buena suerte y podían contrarrestar el pronóstico desfavorable de los adivinos. El diamante es la piedra más dura y por esta razón es considerada símbolo de eternidad.

La leyenda sobre la muerte de Atahualpa cuenta que el Inca promete a los suyos volver a la vida bajo forma de culebra. El retorno del Inca es un tema recurrente en la ideología andina. Por esta razón después de la represión del movimiento revolucionario de Tupac Amaru II, 1781, se prohibirán las representaciones de los hechos de Cajamarca y se ordenará la destrucción de todas las imágenes, vestidos o insignias ligados a la figura del Inca. Creemos que, si bien las disposiciones del corregidor Areche pudieron surtir efecto con respecto a objetos e imágenes, el control sobre otro tipo de expresión cultural de carácter más inefable, como es la danza o la música, pudo haber sido menos efectiva.

No conocemos entonces qué significado pudiera haber tenido el diamante para los incas. Sí sabemos que la luz que en él se refleja produce un arco iris y que este es un importante símbolo en la cultura andina colonial. Según Marcelo Valko, (2005: 13) la simbología del arco iris, para los incas, estaría ligada al concepto de vida eterna y representaría un puente entre la vida y la muerte:

"Hoy en día, el arco iris sigue manteniendo un halo de santidad, carga con un plus valor sígnico, posee una doble herencia incaico-cristiano y sigue manteniendo en su calidad de fenómeno celeste una procedencia divina [...] La relación Inca, arco iris y regreso victorioso posee una indudable proyección temporal” (2005: 15). 
No podemos saber en realidad si la tonada El Diamante ilustra el momento preciso en que Atahualpa entrega un diamante a su hijo. El texto publicado por Lara indica que parte de la tradición quechua consigna este hecho, por lo menos en 1871, aunque hay que reconocer que la ubicación espacial y temporal de las dos "fuentes" es muy diferente.

De todas maneras, y en especial a finales del siglo XVIII, cuando más se interpretaban estas piezas teatrales, el mito de la muerte del Inca estaba largamente difundido en todos los Andes. Por lo tanto, ciertos tópicos ligados al relato de Atahualpa probablemente podían circular en ámbitos espacio-temporal diversos. Podemos imaginar entonces que de alguna manera la tonada El Diamante remita a esta situación. Probablemente la representación teatral retrate el momento en que el Inca entrega el diamante a su hijo mientras el coro de las pallas-ñustas comenta, cantando y bailando, lo emotivo del momento.

Considerando que el códice Martínez Compañón fue realizado entre 1782 y 1785, en plena represión post-revolución Tupac Amaru II, es posible que se representaran los hechos de Cajamarca de manera más disimulada, sin hacer referencia alguna al posible retorno del Inca. Pero en el momento en que Atahualpa se despide de su único hijo, podía aparecer, en el destello de un diamante, un luminoso arco iris.

\section{BIBLIOGRAFÍA}

Acosta, José DE

1591 Historia natural y moral de las Indias. Barcelona http://www.cervantesvirtual.com/obra-visor/historia-natural-y-moral-de-lasindias-en-que-se-tratan-las-cosas-notables-del-cielo-y-elementos-metales-plantas-yanimales-dellas-y-los-ritos-y-ceremonias-leyes-y-gouierno-y-guerras-de-los-indios-0/ html/

Bendezú Edmundo

s/f Literatura quechua. Caracas: Biblioteca Ayacucho.

BiANCONI, LORENZO

1982 "Il Seicento" en Storia della Musica. Volumen 4. Boloña: EDT.

Burgas, Manuel

2005 Nacimiento de una utopia: Muerte y resurrección de los incas. Lima: Fondo editorial.

Claro Valdés, Samuel

1980 “Contribución musical del obispo Martínez Compañón en Trujillo, Perú, hacia fines del siglo XVIII”, RMCh, XXXIV/149-150 (enero-junio), pp. 18-33.

Cieza de León, Pedro

1553 Crónica del Perú. Sevilla: Manuel Ballesteros, editor. http://www.artehistoria.jcyl. es/cronicas/contextos/11495.htm.

Espino Relucé, Gonzalo

2006 "Poéticas quechuas: Garcilaso, Guamán Poma y Anchorena”, Revistas Letras (enerodiciembre), 77/ 111-112. Lima, pp. 93-113. 


\section{Fernández de Oviedo y Gonzalo Valdés}

1526 Sumario de la natural historia de las Indias Toledo. Manuel Ballesteros, editor. http://www.artehistoria.jcyl.es/cronicas/contextos/12541.htm

1547 Cronica de las Indias: la hystoria general de las Indias y con la conquista del Perú. Salamanca: En casa de Juan de Junta.

http:/ /www.memoriachilena.cl/temas/documento_detalle.asp?id=MC0042343

Flores Galindo, Alberto

1987 Buscando un Inca: identidad y utopia en los Andes. Lima: Instituto de Apoyo Agrario.

Gruzczynska Zionkowska, Anna

1995 "El poder del sonido" El papel de las crónicas españolas en la etnomusicología andina [Colecciones Abya Yala 24]. Cayambé Ecuador: Ediciones Abya-Yala.

Guamán Poma de Ayala, Felipe

1615 [1988] Nueva corónica y buen gobierno. Edición a cargo de John V. Murra y Rolena Adorno. México: Siglo XXI Editores [1980 primera edición]. 3 tomos.

JerEZ, Francisco DE

1534 Verdadera relación de la conquista del Perú y conquista del Cuzco. Sevilla.

http://bartomomedelascasas.es/paginas/jerez2.htm

1853-1854 "Verdadera relación de la conquista del Perú y conquista del Cuzco", Historiadores primitivos de Indias. Volumen II. Madrid: Enrique de Vedia.

LARA, JESÚs

1960 La literatura de los quechuas. Cochabamba: Editorial Canelas.

Murúa, Fray Martín de

1611 [1962-64] Historia general del Perú. Origen y descendencia de los Incas. Introducción y notas de Manuel Ballesteros Gaibrois. Prólogo del Duque de Wellington. Madrid: Bibliotheca Americana Vetus, 2 vols. http://www.artehistoria.jcyl.es/cronicas/ contextos/10083.htm

1613 [1964] Historia general del Perú. Madrid: Biblioteca Americana Vetus.

Porras Barrenechea, Raúl

1946 "Notas para una biografía del yaraví", El Comercio, Lima (28 de julio).

1999 El legado quechua. Lima: Fondo Editorial, Universidad Nacional Mayor de San Marco.

STEVEnson, Robert

1959 The Music of Peru: Aboriginal and Viceroyal Epochs. Washington: Pan American Union.

1968 Music in Aztec and Inca Territory. Berkeley y Los Angeles: University of California Press.

Valko, Marcelo

2005 Imágenes, signos e imaginario de la degollación que no fue. http:// hal.archives-ouvertes. $\mathrm{fr} /$ docs/00/15/16/82/PDF/VALKO_Marcelo_L_GIS_2005.pdf

Vega, Carlos

1978 "La obra del obispo Martínez Compañón”, Revista del Instituto de Investigaciones Musicológicas Carlos Vega, II/2, Buenos Aires, pp. 7-17. 
Vega, Garcilaso de LA

1617 Historia general del Perú: trata el descubrimiento del y como lo ganaron los españoles. Cordova : Por la Viuda de Andres Barrera y a su costa. http:/ / www.memoriachilena.cl/temas/documento_detalle.asp?id=MC0014756

1609 [1991] Comentarios reales de los Incas. 2 tomos. Lima: Fondo de Cultura Económica. Edición de Carlos Araníbar. México: Fondo de Cultura Económica. 2 tomos. 